\title{
Endoscopic Pilonidal Sinus Treatment (EPSIT) Experience of a Provincial Hospital in Eastern Turkey
}

\section{Türkiye'nin Doğusunda Bir Taşra Hastanesinin Endoskopik Pilonidal Sinüs Tedavisi (EPSiT) Deneyimi}

\author{
(i) Rıfat Peksöz1, (1) Mehmet Can² \\ ${ }^{1}$ Muş State Hospital, Clinic of General Surgery, Muş, Turkey \\ 2Muş State Hospital, Clinic of Pediatric Surgery, Muş, Turkey
}

\section{HIIIIII| ABSTRACT}

\begin{abstract}
Aim: Pilonidal sinus (PS) is an inflammatory disease of the sacrococcygeal region that negatively affects the life of the individual. Although there are many treatment modalities for the disease, a gold standard treatment method has not yet been determined. It was aimed to compare the endoscopic PS treatment method with other treatment methods in pediatric patients treated for PS in a second-line provincial hospital.

Method: After obtaining approval from Erzurum Regional Training and Research Hospital Ethics Committee with the decision number 2020/0666, pediatric patients under 18 years of age who were operated for PS in Mus Provincial Hospital between January 2017 and January 2020 were retrospectively analyzed. Patients were operated in the prone position, under spinal anesthesia by using total excision + primary closure, total excision + limberg flap, and endoscopic PS treatment (EPSIT) + phenol application methods. Patients' age, gender, length of hospital stay, time to return to work or school, and minor and major complications were analyzed.

Results: Forty eight patients in pediatric age group were included in the study. The average age of the patients was 16,18 years; 20 (41.6\%) of the patients were male and 28 (58.3\%) were female. The hospitalization period was 3,48 days and the average follow-up period was 480 days ( 16 months). Time to return to work was 10,6 (3-28) days. Forty-eight patients underwent surgery. Limberg flap method was used in 13, primary closure method in 9 and EPSIT method in 26 patients. Six patients had recurrence, 5 patients developed minor complications such as seroma and necrotic fat tissue. The hospitalization period was 2 days and the time to return to work was 4.46 days in patients who underwent the EPSIT method, which was superior to the other two methods. The biggest disadvantage of the EPSIT method was the recurrence rate ( $\mathrm{n}=4$ patients, $15.3 \%$ ).

Conclusion: Although the recurrence rate of the EPSIT method with phenol application is high, it is more advantageous than other methods due to the short time to return to work or school and shorter hospital stay.
\end{abstract}

Keywords: Pilonidal sinus, EPSIT, pediatric patient

\section{|IIIIIII| ÖZ}

Amaç: Pilonidal sinüs (PS) bireyin yaşamını olumsuz etkileyen sakrokoksigeal bölgenin enflamatuvar hastalığıdır. Hastalık için birçok tedavi modaliteleri olmasına rağmen henüz altın standart bir tedavi yöntemi belirlenmemiştir. Bu çalışmada, ikinci basamak bir devlet hastanesinde PS nedeniyle tedavi edilen pediyatrik hastalarda endoskopik PS tedavi yöntemi ile diğer tedavi yöntemlerinin karşılaştırılması amaçlanmıştır.

Yöntem: Erzurum Bölge Eğitim ve Araştırma Hastanesi Etik Kurulu’ndan 2020/06-66 karar numarası ile onay alındıktan sonra Ocak 2017-Ocak 2020 arasında Muş Devlet Hastanesi'nde PS nedeniyle ameliyat edilen 18 yaş altı pediyatrik yaş grubu hastalar retrospektif olarak incelendi.Hastalar spinal anestezi altında prone poziyonunda total eksizyon + primer kapama, total eksizyon + limberg flep ve EPSİT + fenol uygulaması yöntemleri uygulanarak ameliyat edildi. Olguların yaşları, cinsiyetleri, hastanede kalış süreleri, işe dönüş ya da okula başlama süreleri, gelişen minör ve major komplikasyonları incelendi.

Bulgular: Çalışmaya 48 pediyatrik yaş grubu hasta dahil edildi. Hastaların yaş ortalaması 16,18 yıl idi. Hastaların 20'si (\%41,6) erkek, 28'i (\%58,3) kadındı. Hastanede yatış süresi 3,48 gün ve ortalama takip süresi 480 gün (16 ay) idi. Hastaların işe dönüş süresi 10,6 (3-28) gün idi. On üçünde limberg fleb yöntemi, 9'unda primer kapama, 26'sında EPSİT yöntemi kullanılarak 48 hastay ameliyat yapıldı. Altı hastada nüks, 5 hastada seroma ve nekrotik yă̆ dokusu gibi minör komplikasyon gelişti. EPSİT yöntemi uygulan hastaların hastanede kalma süresi 2 gün, işe dönüş süresi 4,46 gün idi ve diğer iki yönteme üstün olduğu görüldü. Nüks oranının \%15,3 (n=4) olması bu yöntemin en büyük dezavantajıdır.

Address for Correspondence/Yazışma Adresi: Rıfat Peksöz MD,

Muş State Hospital, Clinic of General Surgery, Muş, Turkey

E-mail: rifat-peksoz@hotmail.com ORCID ID: orcid.org/0000-0003-4658-5254

Received/Geliş Tarihi: 31.03.2020 Accepted/Kabul Tarihi: 24.04.2020

${ }^{\circ}$ Copyright 2020 by Turkish Society of Colon and Rectal Surgery

Turkish Journal of Colorectal Disease published by Galenos Publishing House. 
Sonuç: Fenol uygulamalı EPSIT yönteminde nüks oranı fazla olmakla birlikte işe ya da okula dönüş zamanının kısalığı ve hastanede yatış süresinin az olması nedeniyle bu yöntem diğer yöntemlerden avantajlıdır.

Anahtar Kelimeler: Pilonidal sinüs, EPSIT, pediyatrik hasta

\section{Introduction}

Pilonidal sinus (PS) is a common inflammatory disease of the sacrococcygeal region associated with obesity, sedentary lifestyle, local irritation and hirsutism. Sacrococcygeal PS is more common in young adults, especially in men. ${ }^{1,2}$ The ideal method for PS treatment should have minimal excision and low recurrence rates. Moreover, the best treatment should have features such as short hospitalization time, rapid return to normal life, minimum loss of labor and minimal scar. ${ }^{3}$ There are different approaches in surgical treatment of PS, and in recent years, endoscopic methods have started to be used in PS treatment with the more frequent application of endoscopic methods in different fields of medicine.

In this study, it was aimed to compare endoscopic PS treatment and other surgical methods applied in pediatric patient group in a second-line provincal hospital and to discuss the results on the verge of literature information.

\section{Material and Methods}

Pediatric patients under the age of 18 years who were operated for PS disease in Muş Provincial Hospital between January 2017 and January 2020 were retrospectively analyzed with the Kardelen software system of the hospital after obtaining approval from Erzurum Regional Training and Research Hospital Ethics Committee with the decision number 2020/06-66. Patients were operated in the prone position, under spinal anesthesia by using total excision + primary closure, total excision + Limberg flap, and endoscopic PS treatment (EPSIT) + phenol application methods. A routine drain was placed in the Limberg flap method and primary closure method.

\section{Statistical Analysis}

Age, gender, length of hospital stay, time to return to work, and minor and major complications of the patients were recorded. SPSS 22 program was used for statistical analysis. The one-way analysis of variance (ANOVA) was used for statistical analysis. Cases were expressed as numbers and percentages.

\section{The Stages of The Endoscopic PS Treatment Process}

1: While the patient is in the prone position, both gluteal areas are taped with a plaster and pulled laterally. The surgeon is arranged on the left of the patient with the monitor on the right of the patient.

2: Hairs and debris are cleaned by widening the sinus mouth with a clamp.
3: The cyst is entered with the cystoscope, the hairs and debris are cleaned with the brush sent through the cystoscope, the remaining parts are taken out with forceps.

4: Granulated tissue in the cyst cavity is cauterized with monopolar in the presence of 5\% mannitol (energy used 20 watts)

5: The edges of the sinus mouth are protected with nitrofurazone cream, injected into the cyst cavity $(80 \%$ phenol $+20 \%$ alcohol) and the operation is terminated with wound dressing.

(Figure 1, 2, 3, 4, 5)

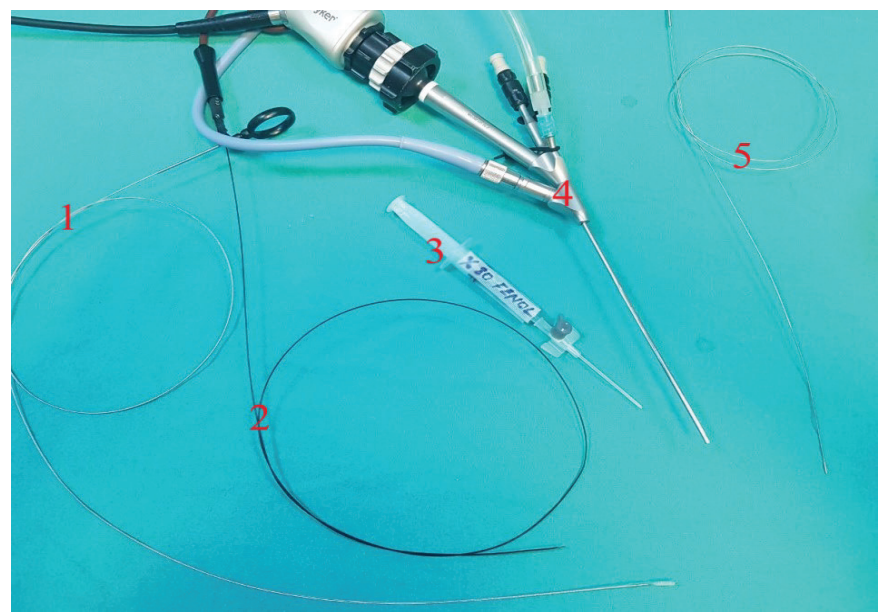

Figure 1. 1: Brush, 2: Monopolar cautery, 3: Phenol fluid, 4: Cystoscope, 5: Forceps

Features of the cystoscope: Cystoscope lensed with an angle of $5^{\circ}$ has optical channel, irrigation channels and working channels. Working channel length is $14 \mathrm{~cm}$, outer diameter of the channel is 6 charr ( $2 \mathrm{~mm}$ ), inner diameter is 5 charr

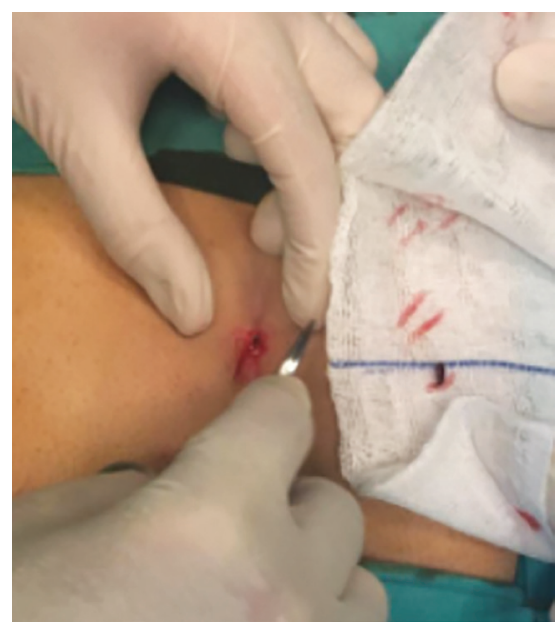

Figure 2. Cleaning the hairs with a clamp with a brush 


\section{Results}

Forty eight patients under the age of 18 years who were operated for PS disease in Muş provincial hospital were examined. The mean age of the patients was $16.18 \pm 1.16$ (12-

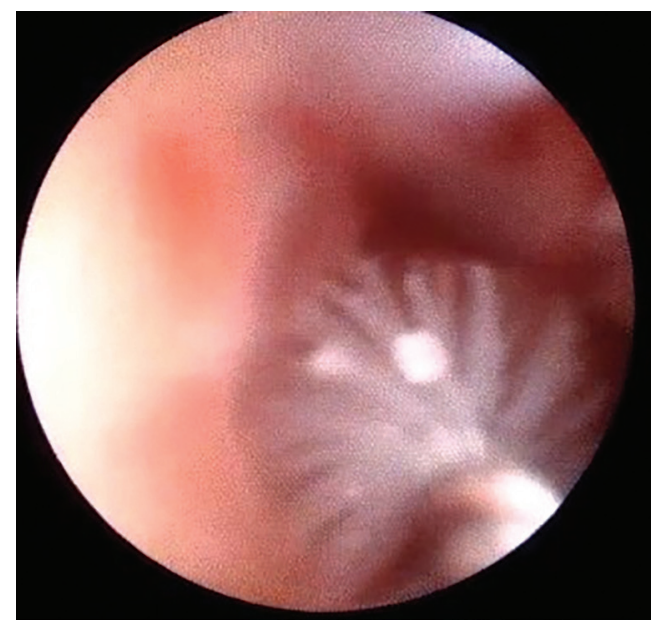

Figure 3. Removing remaining hair and debris

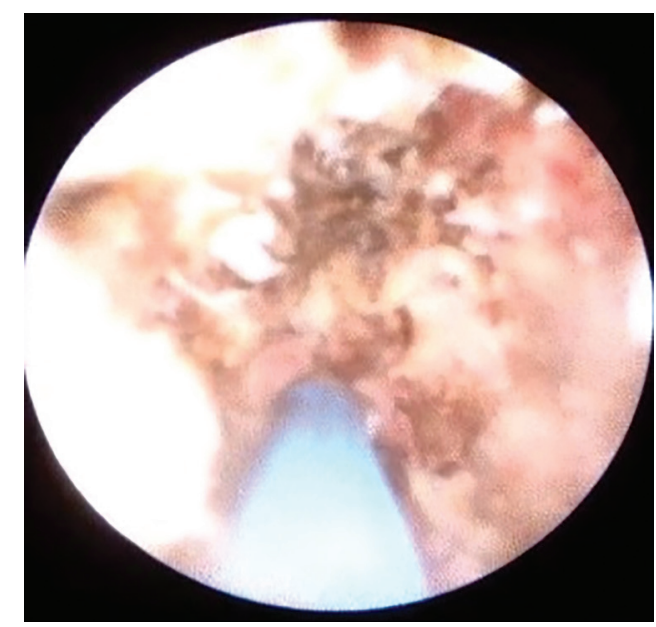

Figure 4. Monopolar cauterization of the cyst cavity

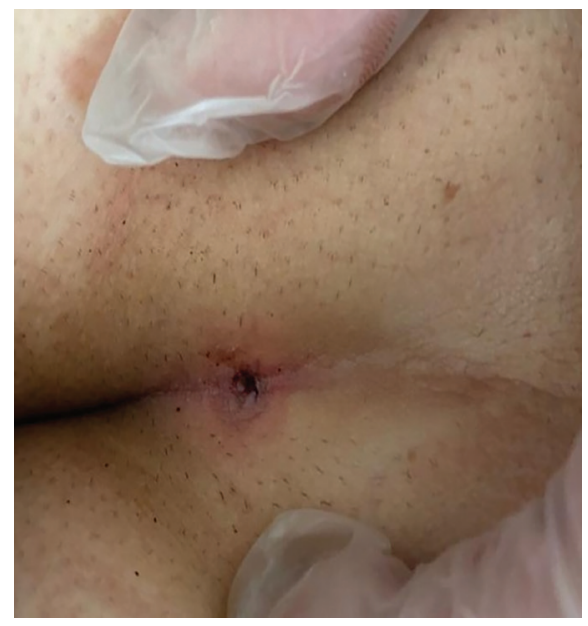

Figure $5.7^{\text {th }}$ day after surgery
18) years, 20 (41.6\%) of the patients were male, 28 (58.3\%) were female. The length of stay in the hospital was 3.48 \pm 1.9 days. The average follow-up period was $480 \pm 196$ days (54780). The time to return to work was $10.6 \pm 8$ (3-28) days. Forty eight patients were operated, including 26 with EPSIT method, 13 with Limberg flap method and 9 with primary closure. The recurrence and minor complication rate in the EPSIT method was 4 (15.3\%), the recurrence and minor complication rate was $1(7.6 \%)$ in the Limberg method, and 1 (11.1\%) patient operated with the primary closure method had recurrence (Table 1 ).

Limberg surgery was performed in 3 of the patients who were operated with the EPSIT method and developed recurrence. Although the superficial tissue ultrasonografi finding of 1 patient was compatible with recurrence, the patient was followed up because he did not have active complaints.

EPSIT method was applied to the patient who was operated with the Limberg method and developed recurrence. The control follow-ups of the patient who developed recurrence following primary closure were not reached.

Stay in the hospital and time to return to work/school were significantly shorter in the EPSIT method, while recurrence rate was significantly higher in the EPSIT method compared with other methods $(p<0.05)$. The effect size of the test was 0.76 .

\section{Discussion}

PS is a common inflammatory disease of the sacrococcygeal region, which is seen especially in young men, significantly affects the quality of life, and can lead to absenteeism in work and school life. ${ }^{4}$ The incidence of the disease is 26/100,000, and it usually occurs in male patients between the ages of 15-30, and it is twice as common in men compared to women. ${ }^{1,2}$

In the study conducted by Biçer et al. ${ }^{5}$ in a group of pediatric patients, the mean age of the patients was 15.9 years and the male/female ratio was 1.7.In the study conducted by Pini Prato et al. ${ }^{6}$, in a group of 43 pediatric patients, the mean age of the patients was 15 years and $53 \%$ of the patients were female. In our study, the mean age of the patients was 16.18 years and $58.3 \%$ of them were girls. The mean age of the patients was consistent with the literature, but unlike many studies in the literature, the rate of female patients was higher. Considering the sociocultural structure of our region; we thought that it was caused by the girls not working but staying at home, the lack of self-care, and the low number of patients in the study.

There are many treatment methods in PS treatment, however these treatments should be simple and effective. Although 
Table 1. Patient characteristics, clinical data and results

\begin{tabular}{|c|c|c|c|c|c|c|c|c|c|}
\hline $\begin{array}{l}\text { Type of } \\
\text { surgery }\end{array}$ & $\begin{array}{l}\text { Number of } \\
\text { patients }\end{array}$ & $\begin{array}{l}\text { Mean age/ } \\
\text { years }\end{array}$ & $\begin{array}{l}\text { Gender } \\
\mathrm{M} / \mathrm{F} \\
\text { ratio }\end{array}$ & $\begin{array}{l}\text { Stay in } \\
\text { hospital/ } \\
\text { days }\end{array}$ & $\begin{array}{l}\text { Follow-up } \\
\text { duration/ } \\
\text { days }\end{array}$ & $\begin{array}{l}\text { Time to return } \\
\text { to work os } \\
\text { school/ days }\end{array}$ & $\begin{array}{l}\text { Minor } \\
\text { complication }\end{array}$ & $\begin{array}{l}\text { Recurrence } \\
\text { rate }\end{array}$ & $\begin{array}{l}\text { Second } \\
\text { surgery } \\
\text { after } \\
\text { recurrence }\end{array}$ \\
\hline EPSIT & $26(54.1 \%)$ & 16.11 & $9 / 17$ & 2 & 414,96 & 4.46 & $4(15.3 \%)$ & $4(15.3 \%)$ & $\begin{array}{l}\text { Limberg } \\
\text { method in } 3 \\
\text { patients }\end{array}$ \\
\hline $\begin{array}{l}\text { Total } \\
\text { excision } \\
+ \text { limberg } \\
\text { flap repair }\end{array}$ & $13(27 \%)$ & 16.07 & $9 / 4$ & 6.25 & 584,46 & 20.23 & $1(7.6 \%)$ & $1(7.6 \%)$ & $\begin{array}{l}\text { EPSIT in } 1 \\
\text { patient }\end{array}$ \\
\hline $\begin{array}{l}\text { Total } \\
\text { excision } \\
\text { + primary } \\
\text { closure }\end{array}$ & $9(18.7 \%)$ & 16.55 & $2 / 7$ & 4.11 & 516 & 14.66 & 0 & $1(11.1 \%)$ & $\begin{array}{l}\text { No follow- } \\
\text { up }\end{array}$ \\
\hline
\end{tabular}

EPSIT: Endoscopic pilonidal sinus treatment, M: Male, F: Female

many techniques have been defined in the last century, there is still no clear treatment procedure., ${ }^{4,7}$

The main method used in PS treatment is surgical excision, and many methods are used to close the defect, such as total excision + primary repair, leaving the wound open, marsupialization, Karydakis method, Limberg flap, and V-Y advancement flap. ${ }^{8}$ Total excision + primary repair and Limberg flap method are commonly used open surgical methods. Some surgeons report good results regarding primary closure, but the problematic side of this method is the high rate of recurrence and infection..$^{9,10}$ In the literature, the recurrence rate in the primary closure method varies between 0 and $42 \%$. In the study by Can et al. ${ }^{11}$, the recurrence rate was $18.4 \%$. The recurrence rate was found to be 3\% in 103 patients operated by Tocchi et al. ${ }^{12}$ with the primary closure technique. In our study, recurrence developed in 1 (11.1\%) patient in whom excision + primary closure method was used and no minor complications developed. The high rate of recurrence was considered due to the small number of patients.

The primary closure method is the ideal method in primary disease, but wide excision and flap methods should be used in most difficult-to-treat patients with recurrence and nonhealing wounds. ${ }^{13}$ In recent years, flap techniques have been at the forefront and have been shown to be superior to primary techniques. However, complications such as dehiscence, seroma and wound infection can be seen. The recurrence rate in flap methods is less than other methods and varies between $0-20 \% .{ }^{14}$ In a large study of 767 patients by Osmanoğlu et al. ${ }^{15}$, recurrence was found in $11.6 \%$ of 300 patients who underwent lesion excision and primary closure, and 193 patients (4.7\%) who underwent Limberg flap. The recurrence rate was $3.1 \%$ and the infection rate was $6.5 \%$ in 353 patients who underwent limberg flap surgery in the study by Mentes et al. ${ }^{16}$. In our study, the rate of recurrence and minor complications in the patient group who were operated with Limberg method was 7.6\% in parallel with the literature.

The size of the incision is inversely proportional to wound healing. In the minimal open incision method, wound healing is faster and the hospital stay is shorter than the wide incision method. ${ }^{17,18}$ In our study, the length of hospital stay and the speed of wound healing were inversely proportional to the size of the incision.

Patient satisfaction is low due to large scarrings in open methods and flap procedures. ${ }^{19}$ On the other hand, minimally invasive techniques are frequently preferred by surgeons and patients because of their advantages such as early discharge from hospital and rapid return to work. ${ }^{20}$ In recent years, with the more frequent use of endoscopic methods in different fields of medicine, endoscopic methods have been used in PS treatment. Endoscopic PS surgery is a new invasive technique that has many advantages over other techniques. This technique allows the surgeon to directly visualize PS, fistula tract and abscess, and to achieve hemostasis. In this technique, the PS and sinus tract are removed endoscopically, hair follicles and keratin debris are destructed, and the granulation tissue can be cauterized. Phenol applied with EPSIT has antiseptic, anesthetic and strong sclerosing properties. Since the external orifice is used for the procedure, it provides good aesthetic results, scar scars up to $5 \mathrm{~mm}$, no stitches and tension. EPSIT has 
advantages such as early return to work, minimal pain, no wound infection and no wound opening., 4,21,22

In the study conducted by Meinero et al. ${ }^{21}$, the mean time to return to work after surgery in a 12-month follow-up was $2 \pm 0.5$ days and the recurrence rate was $5 \%$. The recurrence rate was found to be $5 \%$ in the patient group of 77 patients in whom the EPSIT method was applied by Giarratano et al. ${ }^{4}$ In the study conducted by Prato et al. ${ }^{6}$, the average length of stay in the hospital was $24 \mathrm{~h}$ (12-72 h), the recurrence rate was $12 \%$ and the complication rate was $14 \%$ in a 4 -month follow-up period. In our study, the follow-up period of the patients was 415 days (13.8 months) and the time to return to work was 4.46 days, and the rate of recurrence and minor complications was $15.3 \%$. We think that the high rate of recurrence was due to the patients' lack of self-care and our new EPSIT experience. Patients should be offered postoperative wound care, personal hygiene, and hair epilation to reduce recurrence.

Although the recurrence rate is higher than the other two surgical methods, the EPSIT method is a minimally invasive procedure that can be preferred due to the short duration of hospitalization and short time to return to work or school life.

\section{Study Limitations}

The limitation of our study was that it was a retrospective study and a healthy comparison could not be made due to the low number of patients operated with other methods other than EPSIT. We believe that the examination of patients who are operated with EPSIT and other alternative methods in the same hospital will contribute more to the literature.

\section{Conclusion}

Although PS disease is common in pediatric patients, there are few articles in the literature. Studies on this subject should be increased. Although PS disease is common, a standard treatment method has not been defined yet. The treatment method is determined according to the surgeon's preference, the patient's request, and the extent of the disease. Although the recurrence rates are high, the EPSIT method is a simple, reliable and ideal method that can be accepted by physicians and patients due to the short duration of hospital stay, less time to return to school especially in children. Also, it can be performed even in secondary state hospitals.

\section{Ethics}

Ethics Committee Approval: After obtaining approval from Erzurum Regional Training and Research Hospital Ethics Committee with the decision number 2020/06-66.
Informed Consent: Written informed consent was obtained from all patients of parents.

Peer-review: Internally and externally peer reviewed.

\section{Authorship Contributions}

Concept: R.P., M.C., Design: R.P., M.C., Data Collection or Processing: R.P., M.C., Analysis or Interpretation: R.P., M.C., Literature Search: R.P., M.C., Writing: R.P., M.C.

Conflict of Interest: No conflict of interest was declared by the authors.

Financial Disclosure: The authors declared that this study received no financial support.

\section{References}

1. McCallum IJD, King PM, Bruce J. Healing by primary closure versus open healing after surgery for pilonidal sinus: systematic review and metaanalysis. BMJ 2008;336:868-871

2. De Parades V, Bouchard D, Janier M, Berger A. Pilonidal sinus disease. J Visc Surg 2013;150:237-247.

3. ayhan Z, Zeren S, Duzgun SA, Ucar BI, Alparslan Yumun HN, Mestan M. Crystallized phenol application and modified Limberg flap procedure in treatment of pilonidal sinus disease: A comparative retrospective study. Asian J Surg 2016;39:172-177.

4. Giarratano G, Toscana C, Shalaby M, Buonomo O, Petrella G, Sileri P. Endoscopic pilonidal sinus treatment: long-term results of a prospective series. JSLS 2017;21:e2017.

5. Biçer \$, Özdamar MY. Surgical Approach in Pediatric Patients with Pilonidal Sinus Disease. Arch Basic Clin Res 2019;1:12-15.

6. Pini Prato A, Mazzola C, Mattioli G, Escolino M, Esposito C, D’Alessio A, Abati LC, Leonelli L, Carlini C, Rotundi F, Meinero PC. Preliminary report on endoscopic pilonidal sinus treatment in children: results of a multicentric series. Pediatr Surg Int 2018;34:687-692.

7. Sequeira JB, Coelho A, Marinho AS, Bonet B, Carvalho F, MoreiraPinto J. Endoscopic pilonidal sinus treatment versus total excision with primary closure for sacrococcygeal pilonidal sinus disease in the pediatric population. J Pediatr Surg 2018;53:2003-2007.

8. Mentes BB, Leventoglu S, Cihan A, Tatlicioglu E, Akin M, Oguz M. Modified Limbergtransposition flap for sacrococcygeal pilonidal sinus. Surg Today 2004:34:419-423.

9. Mahdy T. Surgical treatment of the pilonidal disease: primary closure or flap reconstruction after excision. Dis Colon Rectum 2008;51:1816-1822.

10. Brasel KJ, Gottesman L, Vasilevsky CA; Members of the evidence-based reviews in surgery group. Meta-analysis comparing healing by primary closure and open healing after surgery for pilonidal sinus. J Am Coll Surg 2010;211:431-434.

11. Can MF, Sevinc MM, Yilmaz M. Comparison of Karydakis flap reconstruction versus primary midline closure in sacrococcygeal pilonidal disease: results of 200 military service members. Surg Today 2009;39:580586.

12. Tocchi A, Mazzoni G, Bononi M, Fornasari V, Miccini M, Drumo A, Colace L. Outcome of chronic pilonidal disease treatment after ambulatory plain midline excision and primary suture. Am J Surg 2008;196:28-33.

13. Lee PJ, Raniga S, Biyani DK, Watson AJM, Faragher IG, Frizelle FA. Sacrococcygeal pilonidal disease. Colorectal Dis 2008;10:639-650.

14. Akan K, Tihan D, Duman U, Özgün Y, Erol F, Polat M. Comparison of surgical Limberg flap technique and crystallized phenol application in the 
treatment of pilonidal sinus disease: a retrospective study. Ulus Cerrahi Derg 2013;29:162-166.

15. Osmanoglu G, Yetisir F. Limberg flap is better for the surgical treatment of pilonidal sinus. Results of a 767 patients series with an at least five years follow-up period. Chirurgia (Bucur) 2011;106:491-494.

16. Mentes O, Bagci M, Bilgin T, Ozgul O, Ozdemir M. Limberg flap procedure for pilonidal sinus disease; results of 353 patients. Langenbecks Arch Surg 2008;393:185-189.

17. Mohamed HA, Kadry I, Adly S. Comparison between three therapeutic modalities for non-complicated pilonidal sinus disease. Surgeon 2005;3:7377.

18. Lorant T, Ribbe I, Mahteme H, Gustafsson UM, Graf W. Sinus excision and primary closure versus laying open in pilonidal disease: a prospective randomized trial. Dis Colon Rectum 2011;54:300-305.
19. Rao MM, Zawislak E, Kennedy R, Gilland R. A prospective randomised study comparing two treatment modalities for chronic pilonidal sinus with a 5-years follow-up. Int J Colorectal Dis 2010;25:395-400.

20. Isik A, Idiz O, Firat D. Novel Approaches in Pilonidal Sinus Treatment. Prague Med Rep 2016;117: 145-152.

21. Meinero P, Stazi A, Carbone A, Fasolini F, Regusci L, La Torre M. Endoscopic pilonidal sinus treatment: a prospective multicentre trial. Colorectal Dis 2016;18:164-170.

22. Meinero P, Mori L, Gasloli G. Endoscopic pilonidal sinus treatment (E.P.Si.T.) Tech Coloproctol 2014;18:389-392. 